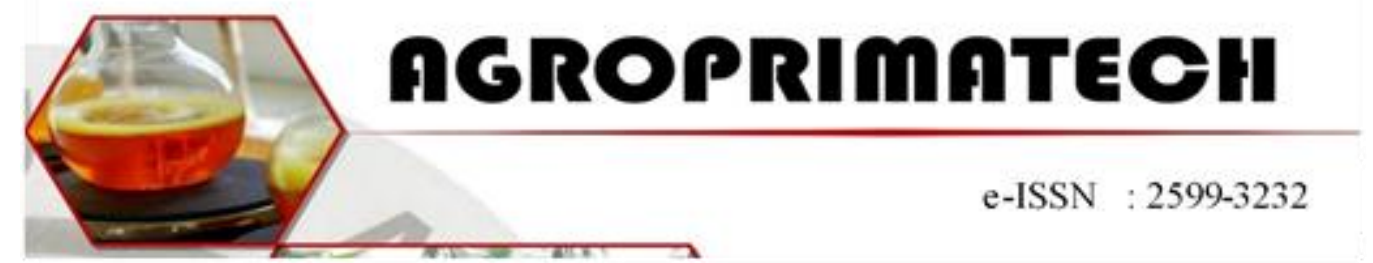

\title{
EFEKTIVITAS PENAMBAHAN PUPUK HAYATI DAN PUPUK NPK TERHADAP PERTUMBUHAN DAN PRODUKSI SELADA (Lactuca sativa L.)
}

\author{
JONNER PURBA ${ }^{1}$, WARLINSON GIRSANG ${ }^{2}$, AGUNG PRATOWO ${ }^{3}$ \\ 1,2Staf Pengajar Prodi Agroteknologi Fakultas Pertanian USI \\ ${ }^{3}$ Mahasiswa Prodi Agroteknologi Fakultas Pertanian USI \\ Email: jonnerpurba@gmail.com
}

\begin{abstract}
ABSTRAK
Penelitian ini dilaksanakan bertujuan untuk melihat Efektifitas Pemberian Pupuk Hayati dan Pupuk NPK Terhadap Pertumbuhan dan Produksi Selada (Lactuca sativa L.) Penelitian dilaksanakan di lahan petani di Desa Pamatang Gajing, Kecamatan Gunung Malela, Kabupaten Simalungun sejak Oktober sampai Desember 2019. Penelitian ini menggunakan Rancangan Acak Kelompok (RAK) Faktorial dengan 2 faktor. Faktor pertama pupuk hayati Petrobio dengan 4 taraf yaitu $\mathrm{H} 0$ (Tanpa pupuk), $\mathrm{H} 1$ (15kg/ha atau $\left.1,5 \mathrm{~g} / \mathrm{m}^{2}\right), \mathrm{H} 2\left(30 \mathrm{~kg} / \mathrm{ha}\right.$ atau $\left.3 \mathrm{~g} / \mathrm{m}^{2}\right), \mathrm{H} 3\left(60 \mathrm{~kg} / \mathrm{ha}\right.$ atau $\left.6 \mathrm{~g} / \mathrm{m}^{2}\right)$. Faktor kedua Pupuk NPK dengan 3 taraf yaitu N1: $\left(100 \mathrm{~kg} / \mathrm{ha}\right.$ atau $\left.10 \mathrm{~g} / \mathrm{m}^{2}\right)$, N2 $\left(200 \mathrm{~kg} / \mathrm{ha}\right.$ atau $\left.20 \mathrm{~g} / \mathrm{m}^{2}\right), \mathrm{N} 3(300 \mathrm{~kg} / \mathrm{ha}$ atau $\left.30 \mathrm{~g} / \mathrm{m}^{2}\right)$. Hasil penelitian menunjukkan bahwa dosis pupuk hayati petrobio dan pupuk NPK menunjukan pengaruh nyata terhadap semua parameter pengamatan, sedangkan interaksi antara pupuk Hayati dan pupuk NPK berpengaruh tidak nyata terhadap semua parameter pengamatan. Pupuk hayati Petrobio degan dosis $60 \mathrm{~kg} / \mathrm{ha}$ memberikan tanaman tertinggi $3 \mathrm{MST}(10,06 \mathrm{~cm}), 4 \mathrm{MST}(12,81 \mathrm{~cm}), 5 \mathrm{MST}(15,52 \mathrm{~cm})$, bobot per tanaman $(149,56 \mathrm{~g})$ dan bobot per plot $(3,26 \mathrm{~kg})$. Pupuk NPK dengan dosis $300 \mathrm{~kg} / \mathrm{ha}$ memberikan tanaman tertinggi $3 \mathrm{MST}(10,10 \mathrm{~cm}), 4 \mathrm{MST}(12,57 \mathrm{~cm}), 5 \mathrm{MST}(15,58 \mathrm{~cm})$, bobot per tanaman $(158,61 \mathrm{~g})$ dan bobot per plot $(3,28 \mathrm{~kg})$.
\end{abstract}

Kata Kunci: Pupuk Hayati, NPK, Selada, Efektivitas, Pertumbuhan

\section{PENDAHULUAN}

Selada (Lactuca sativa L) termasuk ke dalam kelompok tanaman sayuran daun. Jenis sayuran ini mengandung zat-zat gizi khususnya vitamin dan mineral yang lengkap untuk memenuhi syarat kebutuhan gizi masyarakat. Selada sebagai bahan makan sayuran dapat dikonsumsi dalam bentuk mentah sebagai lalapan bersama-sama dengan bahan makaan lainnya. selain berguna untuk bahan makanan saat ini banyak penelitian atau riset yang menjadikan selada sebagai bahan obat-obatan. Mengingat akan pentingnya sayuran selada bagi kesehatan, baik kandungan gizi maupun seratnya, akan mendorong masyarakat semakin menggemari sayuran ini (Wati, 2019)

Produksi selada di Indonesia pada tahun 2015 sebanyak 600.000 ton, pada tahun 2016 sebanyak 601.204 ton, sedangkan tahun 2017 sebanyak 627.611 ton. Terlihat bahwa produksi 
selada di Indonesia dari tahun 2015 dan 2016 mengalami peningkatan sebesar 1.004 ton, sedangkan tahun 2016 dan 2017 produksi selada meningkat jauh yaitu sebesar 26.407 ton. ((BPS, 2017). Peningkatan produksi ini perlu dpertahankan bahkan ditingkatkan sejalan dengan kebutuhan masyarakat yang semakin meningkatn dan mengantisipasi laju pertambahan penduduk yang semakin meningkat pula. Untuk meningkatkan pertumbuhan dalam budidaya selada memerlukan unsur hara. Unsur hara ini dapat berasal dari sumber organik atau anorganik. Ryan (2010) mengatakan bahwa penggunaan pupuk dan pestisida kimia secara terus menerus dapat mengakibatkan rusaknya biota tanah, resistensi hama dan penyakit serta dapat menurunkan kandungan vitamin dan mineral dari sayuran dan buah.

Permasalahan tersebut

dapat ditanggulangi dengan pemupukan. Pemupukan merupakan salah satu faktor yang sangat penting dalam menunjang pertumbuhan dan hasil selada. Pemupukan adalah penambahan unsur hara yang dibutuhkan tanaman sesuai dengan dosis yang dianjurkan. Pemupukan bertujuan untuk memelihara, memperbaiki dan mempertahankan kesuburan tanah dengan memberikan zat-zat pada tanah, sehingga dapat menyumbangkan hara bagi tanaman (Cahyono, 2007).

Unsur hara N, P dan $\mathrm{K}$ merupakan unsur yang sangat dibutuhkan tanaman dalam pertumbuhannya (Gardner, dkk., 1991). Unsur N, P dan K sering disebut sebagai unsur hara makro utama dalam pengertian adalah unusr yang dibutuhkan dalam jumlah banyak dan sangat penting bagi tanaman. Untuk memenuhi unsur hara tersebut di atas pemberian sering dilakukan melalui pupuk majemuk seperti pupuk NPK. Pemberian pupuk majemuk NPK mempunyai beberapa keuntungan diantaranya menghemat waktu, menghemat biaya dan digunakan langsung oleh tanaman.
Wahyuni, $\quad d k k$. mengatakan bahwa pupuk hayati ialah bahan yang mengandung mikroorganisme hidup. Pemberian pupuk hayati diharapkan akan meningkatkan jumlah mikrobia dalam tanah sehingga dapat menambah ketersediaan unsur hara bagi tanaman. Mikroba yang terdapat di dalam pupuk hayati selain mempercepat laju dekomposisi juga dapat memfikasi nitrogen, serta pelarut unsur hara $\mathrm{P}$ dan $\mathrm{K}$ di dalam tanah. Kelompok mikroorganisme tersebut antara lain seperti Rhizobium sp, Azospirilium sp, Azotobacter $s p$, Aspergillus sp, Pseudomonas sp, dan Lactobacillus sp (Manuhuttu dkk., 2014).

Pupuk hayati sangat efektif dalam penyediaan nutrisi dan perbaikan sifat tanah dalam mendukung pertumbuhan tanaman. Menurut Yelianti (2011) Pemanfaatan pupuk hayati bagi tanaman sangat menguntungkan karena dapat menekan penggunaan pupuk kimia yang pada akhirnya dapat mengurangi biaya produksi.

\section{BAHAN DAN METODE}

Penelitian ini dilaksanakan di lahan di Desa Pamatang Gajing, Kecamatan Gunung Malela, Kabupaten Simalungun dengan ketinggian tempat \pm 190 m dpl. Penelitian ini dilakukan bulan Oktober sampai Desember 2019. Peralatan yang digunakan dalam penelitian ini antara lain cangkul, gelas ukur, kertas label, meteran, gembor, alat tulis, timbangan elektrik,dan bambu.

Bahan-bahan yang digunakan dalam penelitian ini antara lain benih selada keriting dengan merek dagang Panah Merah, pupuk kandang, pupuk NPK, pupuk hayati dengan merek dagang Petrobio, Insektisida Decis 25 EC, Dhitane M-45, dan Difolatan $4 \mathrm{~F}$. Penelitian ini menggunakan Rancangan Acak Kelompok (RAK) Faktorial dengan 2 faktor perlakuan. Faktor I adalah pupuk hayati Petrobio dengan 4 taraf dosis Yaitu: HO : Tanpa pupuk hayati petrobio, $\mathrm{H} 1$ : $15 \mathrm{~kg}$ pupuk hayati petrobio/ ha $\left(1,5 \mathrm{~g} / \mathrm{m}^{2}\right), \quad \mathrm{H} 2$ : $30 \mathrm{~kg}$ pupuk hayati 
petrobio/ha $\left(3 \mathrm{~g} / \mathrm{m}^{2}\right), \mathrm{H} 3$ : $60 \mathrm{~kg}$ pupuk hayati petrobio/ha $\left(6 \mathrm{~g} / \mathrm{m}^{2}\right)$. Faktor II adalah Pupuk NPK Dengan 3 Taraf Dosis Yaitu N1: $100 \mathrm{~kg}$ NPK perha (10 $\left.\mathrm{g} / \mathrm{m}^{2}\right)$, N2 : $200 \mathrm{~kg}$ NPK per ha $\left(20 \mathrm{~g} / \mathrm{m}^{2}\right)$, N3 : $300 \mathrm{~kg}$ NPK perha $\left(30 \mathrm{~g} / \mathrm{m}^{2}\right)$

Parameter yang diamati tinggi tanaman 3, 4, dan 5 MST, bobot per tanaman, bobot per plot. Data hasil penelitian dianalisis dengan analisis ragam pada selang kepercanaan $5 \%$. Apabila ada pengaruh nyata perlakuan terhadap parameter yang diamati dlajutkan ke uji beda rata-rata menggunanan uji BNT 5\%.

\section{HASIL DAN PEMBAHASAN}

\section{A. Tinggi Tanaman (cm)}

Hasil Analisis Ragam menunjukkan bahwa pupuk hayati dan pupuk NPK mempengaruhi tinggi akan tetapi kombinasi ke dua perlakukan tidak mempenarugi tinggi tanaman slada pada umur 3, 4 dan 5 MST. Uji bera rata-rata dengan menggunakan uji BNT 5\% dapat dilihat pada tabel.

Tabel 1 menunjukkan bahwa pada dosis $60 \mathrm{~kg} / \mathrm{ha}$ pupuk hayati pertobio $(\mathrm{H} 3)$ diperoleh tanaman tertinggi pada 3, 4 dan 5 MST masing-masing
$10,06 \mathrm{~cm}, 12,81 \mathrm{~cm}$ dan $15,52 \mathrm{cmdimana}$ pada umur 3 dan 4 MST berbeda nyata dengan pemberian $30 \mathrm{~kg} / \mathrm{ha}(\mathrm{H} 2)$, pemberian $15 \mathrm{~kg} / \mathrm{ha}(\mathrm{H} 1)$ dan tanpa pemberian $(\mathrm{H} 0)$. Pada pengamtan $5 \mathrm{MST}$ perlakuan $\mathrm{H} 3$ tidak berbeda nyata dengan $\mathrm{H} 2$ dan $\mathrm{H} 1$ tetapi berbeda nyata dengan $\mathrm{HO}$.

Pupuk hayati Petrobio meningkatkan pertumbuhan tanaman dan semakin banyak dosis yang diberikan pertambahan tinggi tanaman semakin tinggi. Pupuk hayati memiliki peran mendorong dan menstimulasi penambahan unsur hara dalam tanah. Sugiarto (2008) menyatakan bahwa pupuk Hayati Petrobio memiliki bahan aktif bakteri penambat $\mathrm{N}$ bebas tanpa bersimbiosis dengan tanaman dan miktoba pelarut $P$ yaitu Aspergillus niger, Penicilium sp, Pantoe sp, Azospirillum sp, dan Spreptomices $s p$. Kehadiran mikroorganisme tersebut akan mengefektifkan serapan $\mathrm{N}$ dan $\mathrm{P}$ dalam tanah oleh tanaman.

Azospirillium sp merupakan bakteri penambat $\mathrm{N}$ dan menghasilkan zat pengatur tumbuh yang akan merangsang perkembangan akar, pembentukan daun dan pemanjangan sel.

Tabel 1. Hasil Uji Beda Rata-Rata Tinggi Tanaman Selada Akibat Pemberian pupuk Hayati dan Pupuk NPK

\begin{tabular}{clll}
\hline \multirow{2}{*}{ Perlakuan } & \multicolumn{3}{c}{ Rata-rata Tinggi Tanaman Selada $(\mathrm{cm})$} \\
\cline { 2 - 4 } H0 & \multicolumn{2}{c}{3 MST } & \multicolumn{2}{c}{4 MST } & $5 \mathrm{MST}$ \\
\hline H1 & $9,50 \mathrm{~b}$ & $12,13 \mathrm{~b}$ & $14,92 \mathrm{~b}$ \\
$\mathrm{H} 2$ & $9,96 \mathrm{~b}$ & $12,34 \mathrm{~b}$ & $15,46 \mathrm{a}$ \\
$\mathrm{H} 3$ & $10,06 \mathrm{a}$ & $12,56 \mathrm{~b}$ & $15,51 \mathrm{a}$ \\
$\mathrm{N} 1$ & $8,97 \mathrm{~b}$ & $12,01 \mathrm{a}$ & $15,52 \mathrm{a}$ \\
N2 & $9,85 \mathrm{~b}$ & $12,44 \mathrm{~b}$ & $15,01 \mathrm{~b}$ \\
N3 & $10,10 \mathrm{a}$ & $12,57 \mathrm{a}$ & $15,35 \mathrm{~b}$ \\
& & & $15,58 \mathrm{a}$ \\
\hline
\end{tabular}




$\begin{array}{llll}\text { HON1 } & 8,54 & 11,79 & 14,42 \\ \text { H1N1 } & 9,08 & 12,08 & 15,17 \\ \text { H2N1 } & 9,29 & 12,17 & 15,46 \\ \text { H3N1 } & 9,58 & 11,89 & 14,33 \\ \text { HON2 } & 9,96 & 12,42 & 15,08 \\ \text { H1N2 } & 9,50 & 12,81 & 15,67 \\ \text { H2N2 } & 10,08 & 12,11 & 15,31 \\ \text { H3N2 } & 9,58 & 13,13 & 15,65 \\ \text { HON3 } & 10,00 & 12,17 & 15,25 \\ \text { H1N3 } & 9,79 & 12,79 & 15,69 \\ \text { H2N3 } & 10,50 & 12,74 & 15,79 \\ \text { H3N3 } & 11,00 & 13,25 & 16,41\end{array}$

Keterangan: Angka yang diikuti dengan huruf yang tidak sama pada baris dan kolom yang sama berbeda nyata pada uji BNT taraf $5 \%$.

Pembentukan akar yang maksimal akan meningkatkan serapan unsur hara. Harsono dkk., (2017) mengatakan bahwa zat pengatur tumbuh dan vitamin yang dihasilkan oleh mikrobia tertentu merupakan senyawa yang mampu meningkatkan pertumbuhan dan produksi tanaman. Aspergillus niger dan Penicillium sp mempunai kemampuan melarutkan senyawa-senyawa posfat yang sukar larut dan menajdi bentuk yang tersedia bagi tanaman dengan cara menghasilkan asam-asam organik sehingga ketersedian $\mathrm{P}$ lebih cepat.

Pupuk hayati Petrobio berisi mikroorganisme Streptomyces $s p$ berperan sebagai perombak bahan organik (dekomposer), sehingga tanah menajdi gembur, mampu menahan air lebih banyak dan akar tanaman dapat berkembang dengan maksimal. Streptomyces pseudogriseolus merupakan mikroba penghasil antibiotik dan anti jamur. Pupuk hayati ini juga dilengkapi dengan cat pemacu tumbuh eksterna untuk mendukung peningkatkan pertumbuhan tanaman yang pada akhirnya meningkatkan produksi.

Perbedaan dosis pupuk NPK juga mengakibatkan tinggi tanaman yang berbeda seperti terlihat pada tabel 1 . Pada dosis NKP $300 \mathrm{~kg} / \mathrm{ha}$ (N3) diperoleh tanaman tertinggi 3, 4 dan 5 MST masingmasing $10,10 \mathrm{~cm}, 12,78 \mathrm{~cm}$ dan $15,58 \mathrm{~cm}$ yang berbeda nyata dengan dosis 200 $\mathrm{kg} / \mathrm{ha}$ (N2) dan $100 \mathrm{~kg} / \mathrm{ha}$ (N1) pada pengamatan 3 dan $5 \mathrm{MST}$, sedangkan pada pengamatan 4 MST perlakuan N3 tidak berbeda nyata dengan N2. Hasil ini menunjukkan penambahan dosis NPK yang diberikan akan menambah semakin tinggi tanaman.

Dengan pemberian pupuk NPK akan meningkatkan ketersedian unsur hara ini bagi tanaman. Unsur NPK merangsang seluruh proses fisiologi dalam tubuh tanaman termasuk diantaranya untuk pertambahan tinggi tanaman. Lakitan (2011) mengatakan bahwa pertambahan tinggi tanaman merupakan proses fisiologi dimana sel melakukan pembelahan dan pembesaran. Nitrogen $(\mathrm{N})$ dan posfor $(\mathrm{P})$ adalah unsur makro penting bagi tanaman. Nitrogen digunakan tanaman untuk pertumbuhan vegetatif melalui proses pembentukan asam-asam amino dan protein. Protein merupakan senyawa penyusun utama protoplasma yang berfungsi sebagai pusat proses metabolisme dalam tanaman yang selanjutnya akan memacu pembelahan dan pemanjangan sel (Pujisiswanto dan Pangaribuan, 2008). Di samping itu nitrogen secara langsung berperan untuk penambahan jumlah klorofil.

Posfor yang merupakan bagian yang esensial dari berbagai gula posfat, berperan dalam reaksi-reaksi pada fase gelap fotosintesis, respirasi dan berbagai proses metabolisme lainnya. Menurut Marschner (1986) profor berperan sebagai mesin metabolik pada tanaman. Sebanyal 50 jenis senyawa yang terbetuk dari posfor dengan gula dan alkohol. Kebanyakan berperan sebagai senyawa antara reaksi biosintesis dan penguraian. Fungsi posfor lainnya sebagai penyedia 
energi untuk metabolisme dalam sel. Gula posfat berperan dalam reaksi-reaksi gelap fotosintesis, respirasi dan berbagai proses metabolisme lainnya. posfor juga bagian dari nukleotida (dalam RNA dan DNA) dan posfolipid penyusun membran. Kalium berperan sebagai aktivator dari berbagai enzim yang esensial dalam reaksi-reaksi fotosintesis dan respirasi, serta enzim yang terlibat dalam pembentukan protein dan pati, mengatur osmosis sel dan tekanan turgor. Dalam kaitan dengan tekanan turgor, [peran pentingnya adalah dalam pembukaan dan penutupan stomata. Peranan IAA dalam pemanjangan sel dipacu oleh kalium. Kalium dan Asam Giberelat (GA) bersinergi dalam pemanjangan batang. Pemberian kalium bersama-sama dengan GA meningkakan pemanjangan batang.

Kombinasi perlakuan antara dosis pupuk hayati dengan pupuk NPK terhadap tinggi tanaman selada menunjukkan pengaruh tidak nyata. Akan tetapi jika melihat data pengamatan diperoleh gambaran kombinasi pada dosis yang lebih tinggi menyebabkan tanaman lebih tinggi. Tinggi tanaman selada cenderung lebih tinggi dihasilkan oleh kombinasi perlakuan $\mathrm{N} 3 \mathrm{H} 3$ yaitu $11,00 \mathrm{~cm}$ pada umur $3 \mathrm{MST}, 13,25 \mathrm{~cm}$ pada umur 4 MST dan $16,41 \mathrm{~cm}$ pada umur 5 MST.

Dari hasil penelitian diperoleh bahwa pupuk Hayati Petrobio sebagai stimulus ketersediaan unsur hara bagi tanaman belum berperan secara maksimal. Pupuk hayati adalah pupuk yang mengading mikroorgansiem yang fungsinya adalah untuk meningkatkan ketersediaan unsur hara seperti nitrogen, posfor, kalium dan unsur hara lainnya. Pupuk hayati juga disebutkan berperan sebagai starter, di mana mikroorganisme yang ada dalam pupuk melakukan dekomposisi bahan organik yang terdapat dalam tanah. Fungsi melakukan dekomposisi mungkin juga belum maksimal karena umur tanaman selada yang relatif sangat pendek. Glick dkk (2007) mengatakan efektifitas suatu mikroba dalam meningkatkan pertumbuhan tanaman sering tidak terlihat dengan jelas apabila tanaman ditumbuhkan pada kondisi optimum dan bebas stress.

\section{B. Bobot per tanaman (gr)}

Dari hasil analisis ragam diketahui perlakuan dosis pupk Pupuk Hayati dan pupuk NPK berpengaruh nyata namun kombinasi antara keduanya tidak berpengaruh nyata terhadap bobot per tanaman.

Data tabel 2 menunjukkan bahwa pada pemberian pupuk hayati Petrobio dengan dosis $60 \mathrm{~kg} / \mathrm{ha}(\mathrm{H} 3)$ diperoleh rata rata bobot tanaman tertinggi $149,56 \mathrm{gr}$ yang berbeda nyata dengan perlakuan tanpa pemberian pupuk hayati $(\mathrm{H} 0)$ dengan rata-rata 128,61 gr tetapi tidak berbeda nyata dengan pemberian pupuk hayati Petrobio $30 \mathrm{~kg} / \mathrm{ha}(\mathrm{H} 2)$ dengan rata-rata $145,31 \mathrm{gr}$ dan pemberian pupuk hayati Petrobio $15 \mathrm{~kg} / \mathrm{ha}(\mathrm{H} 1)$ dengan rata-rata $141,14 \mathrm{gr}$.

Bobot tanaman mencerminkan tingkat pertumbuhan tanaman, Tombe (2012) menyatakan bahwa pemberian inokulan bakteri pelarut fosfat akan memfasilitasi akar guna meningkatkan dalam penyerapan nutrisi yang tersedia. Meningkatnya hasil tanaman akibat perlakuan bakteri pelarut fosfat diperkirakan selain meningkatkan penyerapan $P$ juga karena bakteri tersebut dapat menghasilkan fitohormon. Bakteri pelarut fosfat juga menghasilkan enzim fosfatase yang berperan dalam mineralisasi $P$ sehingga $P$ yang diserap oleh tanaman menjadi lebih banyak.

Dari tabel 2 menunjukan bahwapemberian pupuk NPK dengan dosis $300 \mathrm{~kg} / \mathrm{ha}$ (N3) dengan rata rata bobot sampel trtinggi rata-rata $158,61 \mathrm{gr}$ yang berbeda nyata dengan pemberian pupuk NPK dengan dosis $100 \mathrm{~kg} / \mathrm{ha}$ (N1) dengan rata-rata 113,22 gr namun tidak brbeda nyata dengan pemberian pupuk NPK dengan dosis $200 \mathrm{~kg} / \mathrm{ha}$ (N2) dengan rata-rata 147,47 gr. Hasil ini menunjukkan semakin tinggi dosis pupuk NPK menyebabkan bobot yang semakin tinggi. 
Tabel 2. Hasil Uji Beda Rata-Rata Bobot per Tanaman pada Pemberian pupuk Hayati dan Pupuk NPK

\begin{tabular}{lc}
\hline Perlakuan & Rata-rata Bobot Per Tanaman $(\mathrm{gr})$ \\
\hline H0 & $128,61 \mathrm{a}$ \\
H1 & $141,14 \mathrm{~b}$ \\
H2 & $145,31 \mathrm{~b}$ \\
H3 & $149,56 \mathrm{~b}$ \\
\hline N1 & $113,22 \mathrm{a}$ \\
N2 & $147,47 \mathrm{~b}$ \\
N3 & $158,61 \mathrm{~b}$ \\
\hline H0N1 & 96,83 \\
H1N1 & 111,58 \\
H2N1 & 131,25 \\
H3N1 & 127,25 \\
H0N2 & 139,00 \\
H1N2 & 148,33 \\
H2N2 & 155,08 \\
H3N2 & 155,67 \\
H0N3 & 150,00 \\
H1N3 & 163,50 \\
H2N3 & 162,33 \\
H3N3 & 153,00 \\
\hline
\end{tabular}

Keterangan: Angka yang diikuti dengan huruf yang tidak sama pada baris dan kolom yang sama berbeda nyata pada uji BNT taraf $5 \%$.

Hal ini terjadi karena pemberian pupuk NPK yang dapat meningkatkan bobot per tanaman. Damanik dkk., (2011) menjelaskan bahwa pupuk NPK berperan dalam metabolisme tanaman yaitu sebagai penghasil energi seperti adp, atp, membangun sel-sel baru, penghasil protein, asam nukleat dan membentuk klorofil. Bila terjadi kekurangan nitrogen akan menghambat pertumbuhan tanaman menyebabkan tanaman kerdil dan daun berwarna kuning pucat dan bila kelebihan daun tanaman akan berwarna hijau tua

Pada perlakuan pemberian dosis pupuk NPK N3 $\left(30 \mathrm{gr} / \mathrm{m}^{2}\right)$ menunjukkan hasil tertinggi terhadap variable bobot per tanaman. Nitrogen merupakan unsur penting dalam penyusunan klorofil merupakan komponen utama dalam proses fotosintesis. Posfor merupakan unsur penyedia enregi untuk pertumbuhan tanaman, demikian juga kalium penting untuk pertumbuhan sebagai penyeimbang osmosis dan tekanan turgor sel dalam pembukaan dan penutupan stomata.

Pada tanaman yang dimanfaatkan (produksi) bagian vegetatifnya maka pertambahan tinggi tanaman berkorelasi positif dengan produksinya. Hasil penelitian ini menunjukkan bahwa pada dosis NPK yang tinggi diperoleh tanaman tertinggi. Erawan et a., I (2013) menyatakan semakin tinggi tanaman, maka akan semakin meningkat pula bobot segar tanaman dan bobot segar konsumsi tanaman tersebut. Demikian juga sebaliknya, ketika pertumbhan tanaman terhambat maka bobot segar tanaman dan bobot segar konsumsi akan rendah. Praetya dkk., (2009) juga mengatakan bobot segar tanam,an dipengaruhi oleh tinggi tanaman, dan luas daun, semakin tinggi tanaman dan semakin besar luas daunnya maka bobot segar tanaman akan semakin tinggi.

\section{Bobot per plot}

Dari hasil analisis ragam diketahui perlakuan dosis pupk Pupuk Hayati dan pupuk NPK berpengaruh nyata namun kombinas antara keduanya tidak berpengaruh nyata terhadap bobot per plot. Dari tabel 3 terlihat pemberian pupuk hayati dengan dosis $60 \mathrm{~kg} / \mathrm{ha}(\mathrm{H} 3)$ diperoleh rata-rata bobot per plot tertinggi yaitu $3,26 \mathrm{~kg}$ yang berbeda nyata dengan 
pemberian pupuk hayati Petrobio dengan dosis $30 \mathrm{~kg} / \mathrm{ha}(\mathrm{H} 2)$ dengan rata-rata 3,16 $\mathrm{kg}$, pemberian pupuk hayati Petrobio dengan dosis $15 \mathrm{~kg} / \mathrm{ha}(\mathrm{H} 1)$ dengan ratarata $3,08 \mathrm{~kg}$ dan perlakuan tanpa pemberian pupuk hayati Petrobio (H0) dengan rata-rata $3,11 \mathrm{~kg}$. Sejalan dengan tinggi tanaman dan bobot per tanaman bobot tanaman per plot juga diperoleh pada pemberin pupuk hayati yang tertinggi.

Hal ini disebabkan oleh kemampuan setiap mikroba yang terdapat di dalam pupuk hayati berbeda beda dalam mensubtitusi unsur hara bagi tanaman dan beradaptasi pada tempat pertumbuhannya, serta kemampuan yang berbeda di setiap varietas dalam bersimbiosis terhadap kandungan mikroba dalam pupuk hayati organik hayati tersebut. Hal ini sejalan dengan (Iskandar, 2002) kemampuan setiap mikroba didalam tanah sangat berbeda beda dalam menyuplai unsur hara, hal ini dapat disebabkan daya adaptasi dan pertumbuhan mikroba tersebut seperti terhadap kemasaman tanah, suhu, kadar air tanah, bahan organik maupun cahaya.

Tabel 3. Hasil Uji Beda Rata-Rata Bobot per Plot Akibat Pemberian pupuk Hayati dan Pupuk NPK

\begin{tabular}{crc}
\hline Perlakuan & $\begin{array}{r}\text { Rata-rata Bobot Per Plot } \\
\text { Selada }(\mathrm{kg})\end{array}$ & $\begin{array}{r}\text { Konversi Bobot per hektar } \\
\text { (ton) }\end{array}$ \\
\hline H0 & $3,11 \mathrm{~b}$ & 7,40 \\
H1 & $3,08 \mathrm{~b}$ & 7,33 \\
H2 & $3,16 \mathrm{~b}$ & 7,76 \\
H3 & $3,26 \mathrm{a}$ & 7,52 \\
\hline N1 & $3,01 \mathrm{~b}$ & 7,16 \\
N2 & $3,17 \mathrm{~b}$ & 7,54 \\
N3 & $3,28 \mathrm{a}$ & 7,80 \\
\hline HON1 & 2,94 & 7,00 \\
H1N1 & 2,96 & 7,04 \\
H2N1 & 3,12 & 7,42 \\
H3N1 & 2,94 & 7,00 \\
HON2 & 3,17 & 7,54 \\
H1N2 & 3,07 & 7,30 \\
H2N2 & 3,26 & 7,76 \\
H3N2 & 3,10 & 7,38 \\
H0N3 & 3,23 & 7,69 \\
H1N3 & 3,20 & 7,61 \\
H2N3 & 3,40 & 8,09 \\
H3N3 & 3,45 & 8,21 \\
\hline
\end{tabular}

Keterangan: Angka yang diikuti dengan huruf yang tidak sama pada barisdan kolom yang sama berbeda nyata pada uji BNT taraf $5 \%$

Dari tabel 3 juga menunjukan pemberian pupuk NPK dengan dosis 300 $\mathrm{kg} / \mathrm{ha}$ (N3) dengan rata rata bobot per plot tertinggi $3,28 \mathrm{~kg}$ berbeda nyata dengan pemberian pupuk NPK demgam dosis $200 \mathrm{~kg} / \mathrm{ha}$ (N2) dengan rata-rata $3,17 \mathrm{~kg}$ dan pemberian pupuk NPK dengan dosis $100 \mathrm{~kg} / \mathrm{ha}(\mathrm{N} 1)$ dengan rata-rata $3,01 \mathrm{~kg}$. Menurut penelitian lqbal (2006) pertumbuhan vegetatif setiap tanaman sangat dipengaruhi oleh komponen hara yang diberikan. Persentase $\mathrm{N}$ yang berbeda pada fase vegetatif tanaman menyebabkan tanaman tersebut mengalami perbedaan dalam proses pertumbuhannya.

Kombinasi pupuk Hayati Petrobio dan dosis Pupuk NPK terhadap bobot per plot menunjukan pengaruh tidak nyata dimana kombinasi yang menghasilkan bobot cenderung lebih tinggi adalah kombinasi perlakuan H3N3 $(3,45 \mathrm{~kg})$ yang apabila dikonversi ke hektar diperoleh 8,21 ton dan bobot cenderung lebih rendah adalah kombinasi perlakuan HON1 $(2,94 \mathrm{~kg})$ yang apabila dikonversi ke hektar adalah 7,00 ton. Berdasarkan hasil di atas untuk tujuan komersial penanaman selada dianjurkan 
memberikan pupuk hayati yang dikombinasikan dengan NPK, mengingat ada perbedaan hasil yang tinggi sekitar 1,2 ton dengan pemberiab Pupuk Hayati dengan dosis $60 \mathrm{~kg} / \mathrm{ha}$ dan NPK 300 $\mathrm{kg} / \mathrm{ha}$ dibandingan tanpa Pupuk Hayati dan dosen NPK $100 \mathrm{~kg} / \mathrm{ha}$.

\section{KESIMPULAN}

Dari hasil peneitian diperoleh kesimulan seperti tertulis di bawah ini :

1. Perlakuan pemberian pupuk hayati petrobio menunjukan adanya pengaruh nyata terhadap tinggi tanaman pada umur 3 MST, 4 MST , $5 \mathrm{MST}$, bobot per tanaman dan bobot tanaman per plot. Pemberian pupuk hayati Petrobio degan dosis $60 \mathrm{~kg} / \mathrm{ha}$ memberikan hasil rata-rata tanaman tertinggi 3 MST $(10,06 \mathrm{~cm}), 4 \mathrm{MST}$ ( $12,81 \mathrm{~cm}), 5 \mathrm{MST}$, (15,52 gr), bobot per tanaman $(149,56 \mathrm{gr})$ dan bobot per plot $(3,26 \mathrm{~kg})$

2. Perlakuan pemberian pupuk NPK menunjukan adanya pengaruh nyata pada parameter tinggi tanaman 3 MST, 4 MST, 5 MST, bobot per tanaman dan bobot per plot. Pemberian pupuk NPK dengan dosis $300 \mathrm{~kg} / \mathrm{ha}$ memberikan hasil rata-rata tanaman tertinggi 3 MST $(10,10 \mathrm{~cm})$, $4 \operatorname{MST}(12,57 \mathrm{~cm}), 5 \mathrm{MST}(15,58 \mathrm{~cm})$, bobot per tanaman ( $158,61 \mathrm{gr})$ dan bobot per plot $(3,28 \mathrm{~kg})$

3. Kombinasi perlakuan pupuk Hayati dan pupuk NPK tidak berpengaruh nyata terhadap tinggi tanaman, bobot per tanaman, dan bobot per plot.

\section{DAFTAR PUSTAKA}

Badan Pusat Statistik, 2017.Produksi Sayuran Selada di Indonesia tahun 2015-2017. Direktorat Jenderal Hortikultura. Jakarta.

Damanik, M.M.B., E.H. Bachtiar., Fauzi., Sarifuddin dan $H$. Hamidah. 2011.Kesuburan Tanah dan Pemupukan. USU Press, Medan
Erawan, D., W. O. Yani, dan A. Bahrun. 2013. Pertumbuhan dan Hasil Tanaman Sawi (Brassica juncea L.) pada Berbagai Dosis Pupuk Urea. Agroteknos 3 (1) : 19-25.

Gardner, E. J., R. B. Pearce, dan R. L. Mitchell 1991. Fisiologi Tanaman Budidaya (Terjemahan). Universitas Indonesia Press.

Glick, B.R., B.Todorovic, J. Czarny, Z. Cheng and J. Dun, 2007. Promotion of Plant Growth by Bacterial ACC Deaminase. Crit. Rev. Plant. Sci. 26: 227-242.

Harsono, A., H. Kuntyastuti dan D. Sucahyono, 2017. Keefetkifat Pupuk Hayati Kayabio, Kayabio plus dan Petrobio untuk Meningkatkan Hasil Kedelai Lahan Tegal dan Sawah Alfisial. Prosiding Seminar Hasil Penelitian Tanaman Aneka Kacang dan Umbi, Balai Penelitian Tanaman Aneka Kacang dan Umbi. JI. Raya Kendal payoh PO Box 66 Malang.

Iskandar, S. S., 2002. Pupuk Hayati Mikoriza untuk Pertumbuhan dan Adaptasi Tanaman di Lahan Marginal

(Online).(http:w.w.w.iptek.Net.ld/

Terapan). Diakses 16 Maret 2020.

Lakitan. 2011. Dasar-Dasar Fisiologi Tumbuhan. PT. Raja Grafindo Persada. Jakarta.

Manuhuttu, A. P, H. Rehatta, dan J.J.G. Kailola, 2014. Pengaruh Konsentrasi Pupuk Hayati Bioboost Terhadap Peningkatan Produksi Tanaman Selada (Lactuca sativa, L), Agrologia Vol. 3No. 1 April 2014 Hal. 18-27.

Marchner, H. 1986. Minerl Nutrition of Higher Plants, Academic PressHarcout Brace Jovanovic Publieher, London 
Agroprimatech

Vol. 4 No. 1, Oktober 2020

Prasetya, B., S. Kurniawan, dan M. Febrianingsih. 2009. (Brassica juncea L.) pada Entisol. Jurnal Agritek 17 (5) : 1022-1029.

Pujisiswanto, $\mathrm{H}$ danD. Pangaribuan. 2008. Pengaruh Dosis Kompos Pupuk Kandang Sapi Terhadap Pertumbuhan dan Produksi Buah Tomat. Prosiding Seminar Nasional Sains dan Teknologi-II 2008 Universitas Lampung, 17-18 November 2008 ISBN : 978-9791165-74-7 VII-11.

Ryan, I. 2010. Respon Tanaman Sawi (Brassica juncea L.) akibat pemberian Pupuk NPK dan Penambahan Bokhasi pada Tanah Asam Bumi Wonorejo Nabire, Jurnal Agroforestri, 5 (4): 310-315.

Sugiarto, Y., 2008. Petrokimia Gresik luncurkan pupuk hayati. (diakses 24 Desember 2018 pada situs http://www.agrina-online.com).

Tombe, O. M. (2012). Pemanfaatan bakteri pelarut fosfat dalam menyediakan fosfat bagi pertumbuhan dan produksi tanaman sawi sendok (Thesis tidak diterbitkan). Fakultas Pertanian, Institut Pertanian Bogor, Bogor.

Wahyuni, S. T. Ismail, H. T. Sebayang dan B. Harsono (2010) Pengaruh Pupuk Hayati Petrobio dan Pupuk NPK pada Pertumbuhan awal Tanaman Jarak Pagar (Jatropa curcas L)

Wati, S. 2019. Jelada Jenis Sayuran yang Makin Diminati di Era Milenial, https://Detik Sultra.Com, 5 Agustus 2019).

Yelianti, U. 2011. Respon tanaman selada (Lactuca sativa L.) terhadap pemberian pupuk hayati dengan berbagai agen hayati. Jurnal Biospecies, 4(2) : 35-39 